\title{
Competitiveness of the agrarian sector: a comparative analysis of Poland and Ukraine
}

\author{
Petro Kurmaiev \\ Pavlo Tychyna Uman State \\ Pedagogical University \\ Uman, Ukraine \\ https://orcid.org/0000-0001-9464-0380 \\ Paraskoviia Kolisnichenko \\ Pavlo Tychyna Uman State \\ Pedagogical University \\ Uman, Ukraine \\ https://orcid.org/0000-0001-6730-1236
}

\author{
Nataliia Vdovenko \\ National University of Life and \\ Environmental Sciences of Ukraine \\ Kyiv, Ukraine \\ https://orcid.org/0000-0003-0849-057X
}

\author{
Marina Pavlenko \\ National University of Life and \\ Environmental Sciences of Ukraine \\ Kyiv, Ukraine \\ http://orcid.org/0000-0002-7513-2425
}

\begin{abstract}
Competitiveness serves an imperative of the long-term economic development. The purpose of the article is to compare the indicators that determine the competitiveness level of the agrarian sector of Poland and Ukraine. In the course of the research, methods of correlation and comparative analysis are used. A review of literary sources on issues of the research has shown the existence of pluralism of approaches to the impact of state support on the competitiveness of the agrarian sector. Results of the analysis showed that the current competitiveness level of the agrarian sector of Poland is higher than in Ukraine. Calculations of the correlation coefficient confirmed the hypothesis of the dependence of gross agricultural products in Poland and Ukraine on the amount of budget expenditures on agriculture. The main problem areas, which negatively influence the competitiveness level of the agrarian sector, are determined.
\end{abstract}

Keywords - competitiveness, agrarian sector, economic development, agricultural output, state support

\section{INTRODUCTION}

During the last decade, there was a complication of the character of world economic processes.

The pace of the dynamics of the economic development of countries depends on many factors, one of which is competitiveness. In our opinion, competitiveness is a generalized characteristic of the ability to implement existing economic, intellectual and other types of potential. It manifests itself at different levels: micro and macroeconomic, global.

The agrarian sector is important in the economy of any country in the world. This is because this sector is not only a producer of goods and provides employment for the population, but also is an important element of the national security of the country.

That is why the competitiveness of the agrarian sector determines not only the efficiency of agricultural producers, but in general, the effectiveness of the social mechanism functioning, its ability to develop.

\section{LITERATURE REVIEW}

Rigorous theoretical and methodological foundations for the research on the competitiveness and productivity of agriculture are presented in [1]. The author critically analyzes existing approaches to determining the competitiveness level of agriculture. In the process of assessing the competitiveness level, more attention is given to non-price competitiveness factors and the impact of state support instruments.

The issue of analyzing the competitiveness level of agriculture at both the global and at the level of individual countries is devoted to scientific work [2]. The research has confirmed the hypothesis that countries that are net exporters of agricultural products have the most competitive positions in the global agro-food markets. The authors emphasize the dominance of the global trend of changing the models of specialization in trade in agricultural products.

The results of research on the competitiveness of agrarian products of the European Union countries in world markets are described in [3]. The calculated index of revealed comparative advantages (revealed comparative advantage index) allowed ranking the EU countries by its value. The countries with the highest level of competitiveness of agricultural and food exports in the EU are identified - the Netherlands, France, Spain. In addition, the calculations showed a tendency to converge the values of the index of comparative advantages found across the EU. To some extent, similar results were obtained in the research of the team of authors [4]. Thus, based on the analysis of empirical data, the authors concluded that the countries that are located in the North-Central regions of the EU, have the highest indicators of agricultural development. Structural and environmental factors are related to the factors that significantly affect the competitiveness of agriculture.

The results of a comparative analysis of the competitive ability of agriculture in Central and Eastern Europe and the EU-15 countries are given in [5]. Using the system of indices and statistical data for the period from 2007 to 2014, 
the authors calculated the level of competitiveness of each sample country. For example, the absolute difference in agricultural productivity of such groups of countries was 1.7 thousand Euros per hectare. In general, the research results have shown that the agricultural competitiveness of the eleven Central and Eastern European countries was lower than the average of the EU-15.

The problem of the competitiveness of agriculture and agri-food products from the countries of South-Eastern Europe, as well as the factors that influence them, is considered in the article [6]. The authors have developed a model that allowed to determine the comparative advantages of agri-food products from the countries of South-Eastern Europe. Interesting are the results of the calculations, which showed that a macroeconomic stability did not significantly affect the competitiveness of agri-food products. At the same time, GDP per capita negatively influenced the competitive ability. While interpreting the results of the calculations, the authors give examples of the countries that despite their low GDP per capita are being successful at the global agricultural market.

\section{MATERIALS AND METHODS}

The theoretical basis of the study is the understanding of competitiveness as a necessary condition for long-term economic development. The correlation analysis was used to study the interdependence of budget expenditures on agriculture per hectare and the volume of gross output per hectare. Comparison of the indicators characterizing the agrarian sector of Poland and Ukraine led to the use of the comparative analysis method. We have used the results of the UN, FAO research.

\section{RESULTS}

Agrarian sectors of Poland and Ukraine have advantages in many characteristics: climatic conditions, agricultural land structure, and the proportion of biologically pure production. Gross output per hectare of agricultural land (tabl.1), expressed in US dollars, decreased, in Poland for the years $2013-2017$ by $12.8 \%$, and in Ukraine by $69.2 \%$ [7, p.471], [8, p.474], [9], [10]. Part of the decrease in this indicator in Ukraine can be explained by the influence of 4 factors: the loss of a certain number of agricultural production and areas in the Crimea and the East of the country, devaluation of the monetary unit, spread of raiding, decrease in the volume of capital investments.

TABLE I. THE DYNAMICS OF INDIVIDUAL INDICATORS THAT ChARACTERIZE THE EFFICIENCY OF THE FunCTIONING OF THE AGRICULTURAL SECTORS OF POLAND AND UKRAINE

\begin{tabular}{|c|c|c|c|c|c|c|}
\hline \multirow{2}{*}{ Indicators } & \multicolumn{2}{|c|}{$\mathbf{2 0 1 3}$} & \multicolumn{2}{|c|}{$\mathbf{2 0 1 5}$} & \multicolumn{2}{c|}{$\mathbf{2 0 1 7}$} \\
\cline { 2 - 7 } & $\boldsymbol{P L}$ & $\boldsymbol{U A}$ & $\boldsymbol{P L}$ & $\boldsymbol{U A}$ & $\boldsymbol{P L}$ & $\boldsymbol{U A}$ \\
\hline $\begin{array}{c}\text { Agricultural } \\
\text { output per } \\
\text { 1 ha of } \\
\text { agricultural } \\
\text { land, USD }\end{array}$ & 2453 & 711,5 & 1798,9 & 257,2 & 2137,2 & 219,3 \\
\hline $\begin{array}{c}\text { Livestock } \\
\text { production } \\
\text { index }\end{array}$ & 108,0 & 104,9 & 109,7 & 99,2 & 110,8 & 94,9 \\
\hline $\begin{array}{c}\text { Cereal yield } \\
\text { (kg per } \\
\text { hectare) }\end{array}$ & 3804 & 4030 & 3727 & 4140 & 4199 & 4315 \\
\hline
\end{tabular}

Source: [7, p.471], [8, p.474], [9]-[12]
For example, the national currency of Ukraine devalued in relation to the US dollar in, more than, 3.2 times. The volume of capital investments per hectare of agricultural land decreased from \$ 57.6 million during 2013-2017 up to 54 dollars $(-6.25 \%)$ [10], [13]. The minimum value during the specified period was observed in 2015 - 27.7 dollars / ha [10], [13].

During the analyzed period, the Polish zloty devalued by about $20 \%$, the volume of investments increased from 106 USD / ha to $111.6 \mathrm{USD} /$ ha $(+5.2 \%)$ [7, p.665], [8, p.670].

Devaluation processes in both countries were multivectored. In Ukraine, devaluation, along with a positive impact on the competitiveness of domestic goods exports at the expense of price parameters, significantly increased the cost of the purchase of new equipment, technologies, fertilizers, fuel and lubricants. The modest rate of devaluation of the zloty had a positive effect on the competitiveness of Polish agrarian exports.

Separately, it is necessary to dwell on the issue of state support for the agrarian sector.

The toolkit for supporting selected sectors of the economy is widely used by many countries in the world.

Separate studies [14], [15] indicate the controversial nature of state support for agriculture, its impact on competitiveness and other economic parameters. At the same time, the results of many empirical studies [16], [17] indicate the positive impact of state support on the introduction of new technologies in agriculture.

In our opinion, expansion into new markets and / or production of goods in socially important sectors requires different forms of state support.

The volume of budget expenditures per hectare of agricultural land had a downward trend in both countries. In Poland, this indicator decreased by $37.6 \%$ [7, p.648], [8, p.653] during 2013-2017, in Ukraine by 55.3\% [18], [19].

In the course of the research, it is expedient to check the hypothesis that the dynamics of the gross agricultural production of Poland and Ukraine depends on the amount of budget expenditures on agriculture.

In order to test this hypothesis, a tool of the correlation analysis was used. The correlation coefficient we have calculated for the volume of budget expenditures per hectare of agricultural land and gross output per 1 ha testified to the existence of a close connection between them. The correlation coefficient for Poland is 0.8 , for Ukraine 0.91.

To date, the issue of the practice of using certain forms of state support - direct subsidies (EU countries) or lending (Canada) or other forms remains controversial.

In Ukraine, state support for agriculture combines different forms - from fiscal stimulation (single tax 4 group, until 2017 - special VAT regime) to direct subsidies and lending. State support for agro production in Ukraine is not systemic; the volume of financial resources is limited. For example, the volume of funding for major agricultural development programs for 2014-2017 was about \$ 607.4 million [20]. This amount is not enough to implement the main measures to increase the competitiveness of national commodity producers. 
Poland has more opportunities to support agricultural producers.

This is due both to a higher degree of economic development and society, and to the access to supranational foundations, for example, the EU. Expenditures under the Common Agricultural Policy program for 2013-2017 amounted to about \$ 24 billion; within the framework of the Rural Development Program (2014-2020), financing is estimated at 13.6 billion euros, of which 8.6 billion euros at the expense of the EU [21].

The funds provided by the indicated programs were aimed mainly at the modernization of production, certification of products. This, in turn, contributed to increasing the competitiveness of Poland's agrarian production in world agricultural markets. During 20132017, the overall dynamics of agricultural exports from Poland and Ukraine was positive, with growth of $14.8 \%$ and $4.3 \%$ respectively.

Analyzing the export of agricultural products in Poland and Ukraine, it is advisable to highlight the following trends.

First, the change in the structure of agrarian exports (tabl. 2). The most dynamic growth of agricultural product groups of agricultural exports was observed in terms of structure and value in terms of finished products.

Thus, during the years 2013-2017, the share of finished products increased by $8.4 \%$ and amounted to $50 \%$ [7, p.568], [8, p.572]. During this period, Polish companies actively entered new markets for finished products, in particular Ukraine.

TABLE II. The Structure OF Agricultural EXPorts OF POLAND AND UKRAINE \%

\begin{tabular}{|l|l|l|l|l|l|l|}
\hline \multirow{2}{*}{ Sections } & \multicolumn{2}{|c|}{$\mathbf{2 0 1 3}$} & \multicolumn{2}{c|}{$\mathbf{2 0 1 5}$} & \multicolumn{2}{c|}{$\mathbf{2 0 1 7}$} \\
\cline { 2 - 7 } & $\boldsymbol{P L}$ & $\boldsymbol{U A}$ & $\boldsymbol{P L}$ & $\boldsymbol{U A}$ & $\boldsymbol{P L}$ & $\boldsymbol{U A}$ \\
\hline $\begin{array}{l}\text { Live animals; } \\
\text { animal } \\
\text { products }\end{array}$ & 35,5 & 6,4 & 31,0 & 5,6 & 32,6 & 6,2 \\
\hline Crop products & 20,2 & 52,1 & 18,1 & 54,7 & 15,8 & 51,9 \\
\hline Fats and oils & 2,7 & 20,6 & 2,5 & 22,6 & 1,6 & 25,9 \\
\hline $\begin{array}{l}\text { Prepared } \\
\text { foodstuffs }\end{array}$ & 41,6 & 20,9 & 48,4 & 17,1 & 50,0 & 16,0 \\
\hline
\end{tabular}

Source: [7, p.568], [8, p.572], [22, p.31], [23, p.25]

The share of finished goods in the structure of Ukrainian agrarian exports decreased by $4.9 \%$ and amounted to $16 \%$ in 2017 [22, p.31], [23, p.25]. Ukrainian businesspersons have been forced to lose some of the traditional markets, and reorientation on new ones has not always been effective.

The largest share of Ukrainian agricultural exports was crop production, although its share decreased from $52.1 \%$ in 2013 to $51.9 \%$ in 2017 . The basis for the export of plant products was grain crops (wheat and maize), as well as seeds of oilseeds (soybeans, rapeseeds). The share of crop production in Polish agrarian exports decreased more significantly, from $20.2 \%$ to $15.8 \%$ (tabl. 2).

In the structure of Ukrainian agrarian exports, the share of fats and oils has grown significantly. It increased over the years $2013-2017$ by $5.3 \%$ to $25.9 \%$.

The share of livestock products declined in the overall structure of agricultural exports of both countries: in Poland
- from $35.5 \%$ to $32.6 \%(-2.9 \%)$, in Ukraine - from $6.4 \%$ to $6.2 \%(-0,2 \%)$.

In general, absolute and relative indicators of Polish agrarian exports point to a higher degree of equilibrium than the Ukrainian ones. The results of the above analysis show a higher level of competitiveness of Polish agrarian commodity producers. This is also confirmed by high rates of the growth of Polish agrarian exports both in traditional markets (for example, in EU countries) and in new ones (Algeria).

The effectiveness of the statutory regulation is an important factor in the competitiveness of the subjects of agrarian entrepreneurship. In 2017, Poland ranked 24th in the Doing Business rating [24], having improved it by 31 points in comparison with 2013. Under the "Trading across Borders" sub-index, Poland occupies the first position in the world, with the sub-index "Protecting Minority Investors" 42. Ukraine, during the specified period, improved the overall position by 57 points, and in 2017, it occupied 80 positions [24]. Positive dynamics was observed with regard to sub-indices "Trading across Borders" (115th place, improvement by 30 points), "Protecting Minority Investors" (70th place, improvement by 47 points) [24]. It is obvious that the growth of the competitiveness of the agrarian sector will require more dynamic changes in the field of the statutory regulation, in the first place, in terms of fighting corruption and raiding.

Thus, if for the agrarian sector of Poland the problem of combating corruption is not a priority, then for Ukraine it has become strategically important. Thus, in the rating of Corruption Perceptions Index in 2017, Poland occupied the 36th position, Ukraine - the 130th [25]. High level of corruption in Ukraine leads to the ineffective system of distribution of state subsidies to agricultural producers, growth of additional expenses by business entities, complication of protection of property and other rights. In addition, for Polish agribusiness, the phenomenon of raiding is not well-known. Instead, for Ukraine, raids became a problem of a state scale - 2321 raider hijackings were recorded during 2013-2017 [26]. Ineffectiveness of legal mechanisms for the protection of property rights negatively affects the attraction of foreign investment, the creation of the newest competitive agrarian productions.

The issue of purchase and sale of agricultural land is a matter of argument in Ukraine. Nowadays Articles 14, 15, Section 10 of the Land Code of Ukraine [27] have introduced a moratorium on the sale of agricultural land until January 01, 2020. The moratorium on land sales has delayed the sale of land for 18 years. During this period, it was possible to carry out the necessary institutional and legislative changes, in particular to adopt the Land Commerce Law and a number of bylaws. It would also be expedient to organize an information campaign to inform the public about the benefits and threats of land turnover. The results of a sociological survey [28], conducted in June, 2019 indicate that $68 \%$ of people are against the purchase and sale of land, $20 \%$ support this idea and $12 \%$ are undecided. Similar results were shown in October and November 2018 [29]. It means that Ukrainian society is not yet ready for free land turnover. 
In our opinion, the issue of purchase and sale of agricultural land should be considered exclusively in the context of the land market formation. The moratorium elimination will not allow to get the maximal effect due to the high level of corruption, low efficiency of public institutions, and lack of adequate infrastructure. At the same time, the need for development and implementation of measures aimed at forming a civilized land market in Ukraine is obvious.

\section{CONCLUSIONS}

The results of the analysis showed that the current level of competitiveness of the agrarian sector of Poland is higher than in Ukraine. Traditional factors of competitiveness of the agrarian sector, for example, the quality of soils, in modern conditions, are not decisive. The factors associated with the introduction of the latest technologies, the formation of the knowledge economy in the agricultural sector are emerging. They will determine the level of competitiveness of the agrarian sector in the long run. Formation of a favorable business environment could be a catalyst for positive changes in the agrarian sector of Ukraine. This will, on the one hand, increase the attractiveness of the agricultural sector of Ukraine for domestic and foreign investors, on the other hand, will create the preconditions for more efficient use of available resources of state aid to agriculture, reduce the level of transaction costs. In this context, the formation of a civilized land market will have a positive impact on the competitiveness of Ukrainian agriculture. The initial stage of its formation should be the legal and regulatory framework of relations in this area. At the same time, it is advisable to create institutions aiming at the organization of the land market functioning. Promising are also the research related to the analysis of organic farming practices in different European countries and determining the demand for organic agricultural products.

\section{REFERENCES}

[1] L. Latruffe, "Competitiveness, Productivity and Efficiency in the Agricultural and Agri-Food Sectors", OECD Food, Agriculture and Fisheries Papers, no. 30, p.p. 1-63, 2010. http://dx.doi.org/10.1787/5km91nkdt6d6-en.

[2] A. Jambor, and S. Babu, "The Competitiveness of Global Agriculture", in Competitiveness of Global Agriculture, A. Jambor and S. Babu, Eds. Cham, Switzerland: Springer, 2016, p.p. 99-129. https://doi.org/10.1007/978-3-319-44876-3_6.

[3] S. Bojnec, and I. Ferto, "Agri-Food Export Competitiveness in European Union Countries", Journal of Common Market Studies, vol. 53. no 5, p.p. 447-492, 2015. https://doi.org/10.1111/jcms.12215.

[4] E. Giannakis, and A. Bruggeman, "The highly variable economic performance of European agriculture", Land Use Policy, vol. 45, p.p. 26-35, 2015. https://doi.org/10.1016/j.landusepol.2014.12.009.

[5] Statistical yearbook of the republic of Poland 2015. Warsaw, Poland: Statistical publishing establishment, 2016.

[6] A. Nowak, "The competitiveness of agriculture of EU member countries of Central and Eastern Europe", Acta Sci. Pol., Oeconomia, no. 15 (2), p.p. 113-125, 2016.

[7] B. Matkovski, K. Branimir, S. Zekic, and M. Jeremic, "Agri-Food Competitiveness in South East Europe", Outlook on Agriculture, no. 20 (10), p.p. 1-10, 2019. doi:10.1177/0030727019854770

[8] Statistical yearbook of the republic of Poland 2018. Warsaw, Poland: Statistical publishing establishment, 2019.

[9] Agriculture, forestry and fishery. State Statistics Service of Ukraine, 2019. [Online]. Available: http://www.ukrstat.gov.ua/. Accessed on: May 23, 2019
[10] Land Fund of Ukraine as of 1 January 2016, and the dynamics of its changes in comparison with data of January 1, 2015. State Land Cadastre, 2016. 2 [Online]. $\quad$ Available: http://land.gov.ua/info/zemelnyi-fond-ukrainy-stanom-na-1-sichnia2016-roku-ta-dynamika-iohozmin-u-porivnianni-z-danymy-na-1sichnia-2015-roku/. Accessed on: May 23, 2019.

[11] Cereal yield (kg per hectare). The World Bank Group, 2019. [Online]. Available:

https://data. worldbank.org/indicator/AG.YLD.CREL.KG?end=2017\& locations=PL-UA-1W\&start=2013. Accessed on: May 23, 2019.

[12] Livestock production index $(2004-2006=100)$. The World Bank Group, 2019. [Online]. Available: https://data.worldbank.org/indicator/AG.PRD.LVSK.XD?end=2016\& locations $=$ PL-UA\&start=2013\&view=chart. Accessed on: May 23, 2019

[13] Capital investment. State Statistics Service of Ukraine, 2019. [Online]. Available:: http://www.ukrstat.gov.ua/. Accessed on: May 25, 2019

[14] N. M. Trendov, O. Kehinde, and P. Mile, "Are agricultural subsidies efficient tool for agricultural sector of the Republic of Macedonia?" Bulg. J. Agric. Sci., vol.23, no. 3, p.p. 363-369, 2017.

[15] M. Pechrová, "Impact of the Rural Development Programme Subsidies on the farms' inefficiency and efficiency", Agricultural Economics, vol. 61, p.p. 197-204, 2015

[16] L. Cimpoies, "Subsidies and their impact on the competitiveness of the agricultural sector in Moldova" in Proc. 7th Int. Conf. Rural Development, Kaunas, 2015, pp. 1-5. http://doi.org/10.15544/RD.2015.096.

[17] B. C. Cin, Y. J. Kim, and N. S. Vonortas, "The impact of public R\&D subsidy on small firm productivity: evidence from Korean SMEs", Small Bus Econ, vol.48, p. 345, 2017. https://doi.org/10.1007/s11187-016-9786-x.

[18] Expenditure. CASE Ukraine, 2018. [Online]. Available: http://cost.ua/en/budget/expenditure/. Accessed on: May 23, 2019

[19] V.V. Zubenko et al., Budget Monitoring: Analysis of Budget Execution in 2015. Kyiv, Ukraine: IBSER, 2016.

[20] Funding from the State Budget. The Ministry of Agrarian Policy and Food of Ukraine, 2019. [Online]. Available: https://minagro.gov.ua/ua/napryamki/finansova-

politika/finansuvannya-z-derzhavnogo-byudzhetu. Accessed on: May 25, 2019

[21] Rural Development Program 2014-2020. The Ministry of Agriculture and Rural Development of Poland, 2019. [Online]. Available: https://www.gov.pl/web/rolnictwo/-program-rozwoju-obszarowwiejskich-2014-2020-prow-2014-2020. Accessed on: May 25, 2019.

[22] Ukrain`s foreign trade: Statistical Yearbook 2017. Kyiv, Ukraine: State Statistics Service of Ukraine, 2018

[23] Ukrain`s foreign trade: Statistical Yearbook 2015. Kyiv, Ukraine: State Statistics Service of Ukraine, 2016

[24] Rankings \& Ease of Doing Business Score. Doing Business, 2019. [Online]. Available: https://www.doingbusiness.org/en/rankings. Accessed on: May 25, 2019.

[25] Corruption Perceptions Index. Transparency International 2018. [Online]. Available: https://www.transparency.org/news/feature/corruption_perceptions_in dex_2017. Accessed on: May 25, 2019

[26] Since 2014, the number of corporate raids increases every year. Opendatabot, $2018 . \quad$ [Online]. Available: https://opendatabot.ua/blog/198-raiders. Accessed on: May 25, 2019

[27] The Land Code of Ukraine. Legislation of Ukraine, 2019. [Online]. Available: https://zakon2.rada.gov.ua/laws/show/2768-14. Accessed on: May 23, 2019

[28] Public Opinion Survey of Residents of Ukraine. International Republican Institute, 2019. [Online]. Available: https://www.iri.org/sites/default/files/july_2019_ukraine_poll.pdf. Accessed on: June 30, 2019

[29] Monitoring of the electoral moods of Ukrainians. Rating Group Ukraine, 2018. [Online]. Available: http://ratinggroup.ua/en/research/ukraine/354a0dde7bc4bd5e6fa291b 0bd1dc997.html. Accessed on: June 30, 2019 